Marquette University

e-Publications@Marquette

Biological Sciences Faculty Research and

Publications

Biological Sciences, Department of

2-1989

\title{
Methylation of Replicating and Nonreplicating DNA in the Ciliate Tetrahymena thermophila
}

Gail Singer Harrison

Brandeis University

Kathleen M. Karrer

Marquette University, kathleen.karrer@marquette.edu

Follow this and additional works at: https://epublications.marquette.edu/bio_fac

Part of the Biology Commons

\section{Recommended Citation}

Harrison, Gail Singer and Karrer, Kathleen M., "Methylation of Replicating and Nonreplicating DNA in the Ciliate Tetrahymena thermophila" (1989). Biological Sciences Faculty Research and Publications. 228.

https://epublications.marquette.edu/bio_fac/228 


\title{
Methylation of Replicating and Nonreplicating DNA in the Ciliate Tetrahymena thermophila
}

\author{
GAIL SINGER HARRISON ${ }^{\dagger}$ AND KATHLEEN M. KARRER* \\ Brandeis University, Department of Biology, Waltham, Massachusetts 02254
}

Received 5 August 1988/Accepted 27 October 1988

\begin{abstract}
Methylation of adenine in replicating and nonreplicating DNA of the ciliate Tetrahymena thermophila was examined. In growing cells, $87 \%$ of the methylation occurred on the newly replicated daughter strand, but methylation was also detectable on the parental strand. Methylation of nonreplicating DNA from starved cells was demonstrated.
\end{abstract}

The modified base $N^{6}$-methyladenine $\left(N^{6} \mathrm{MeA}\right)$ is present as a minor component in DNA from several unicellular eucaryotes, including members of the genera Chlamydomonas (9), Chlorella (16), Oxytricha (15), Paramecium (2), and Tetrahymena (9). DNA in the germ line micronucleus in Tetrahymena thermophila is unmethylated, while $0.8 \%$ of adenines in DNA of the somatic, polyploid macronucleus are modified to $\mathrm{N}^{6} \mathrm{MeA}$ (3). The function of $\mathrm{N}^{6} \mathrm{MeA}$ in $T$. thermophila is not known.

During sexual reproduction, the old macronucleus is destroyed and a new macronucleus develops from a mitotic product of the zygotic micronucleus. De novo methylation of DNA in the developing macronucleus is not random but occurs according to a specific pattern. Some GATC sites, for example, are unmethylated while others are methylated in all macronuclear DNA molecules (6). Still others are methylated in a fraction of the molecules that is characteristic of a particular site and that is consistent between cell lines $(1,17$; Capowski et al., submitted for publication). Because $T$. thermophila undergoes phenotypic assortment (for a review, see reference 13), the existence of partially methylated sites implies that there is a methylase in vegetative cells which recognizes unmethylated DNA as a substrate.

Methylation of replicating DNA. If de novo methylation contributes to maintenance of the methylation pattern, then both the newly synthesized strand and, to a lesser extent, the parental strand are expected to undergo methylation in replicating DNA. Vegetatively growing cells were cultured in axenic medium containing $1 \%$ proteose peptone (4) to a density of $3 \times 10^{5}$ cells per ml. Bromodeoxyuridine (BUdR; $50 \mu \mathrm{g} / \mathrm{ml})$ and $\left[\right.$ methyl $\left.-{ }^{3} \mathrm{H}\right]$ thymidine $(55$ to $80 \mathrm{Ci} / \mathrm{mmol}$; concentration, 0.5 to $1.0 \mathrm{mCi} / \mathrm{ml}$ ) were added to the medium, and the cells were grown for an additional $270 \mathrm{~min}(1.5$ generations). Nuclear DNA was purified as described previously (6). The parental and daughter strands of the newly replicated DNA were separated on alkaline $\mathrm{CsCl}_{2}-\mathrm{Cs}_{2} \mathrm{SO}_{4}$ gradients (12) with $3.9 \mathrm{~g}$ of $\mathrm{CsCl}_{2}$ in each 4.8 -ml gradient.

After BUdR was incorporated into the DNA and the DNA was labeled with $\left[{ }^{3} \mathrm{H}\right]$ thymidine, approximately $40 \%$ of the DNA, which was assayed by $A_{260}$ determination, migrated as a broad peak with a heavy density (Fig. 1a). The majority (92\%) of newly replicated DNA, which was labeled with $\left[{ }^{3} \mathrm{H}\right]$ thymidine, migrated in the gradient as a heavy peak. Thus, replicating DNA was efficiently labeled and there was

* Corresponding author.

$\dagger$ Present address: University of Colorado Health Sciences Center, Division of Medical Oncology, Denver, CO 80262. good separation of newly replicated daughter strands from unreplicated parental strand DNA.

Since $T$. thermophila does not synthesize purines and pyrimidines (11), DNA was labeled with methionine only by postreplicative methylation of adenine (14) (see Table 2). A gradient of DNA from cells dividing in the presence of BUdR and $\mathrm{L}-\left[\right.$ methyl $\left.-{ }^{3} \mathrm{H}\right]$ methionine $(12$ to $80 \mathrm{Ci} / \mathrm{mmol})$ at 8 to 25 $\mathrm{Ci} / \mathrm{ml}$ is shown in Fig. 1b. The majority of counts $(87 \%)$ comigrated with newly synthesized (heavy) DNA.

In contrast to DNA labeled with $\left[{ }^{3} \mathrm{H}\right]$ thymidine, $\left[{ }^{3} \mathrm{H}\right] \mathrm{me}$ thionine-labeled DNA produced a small but distinct peak of
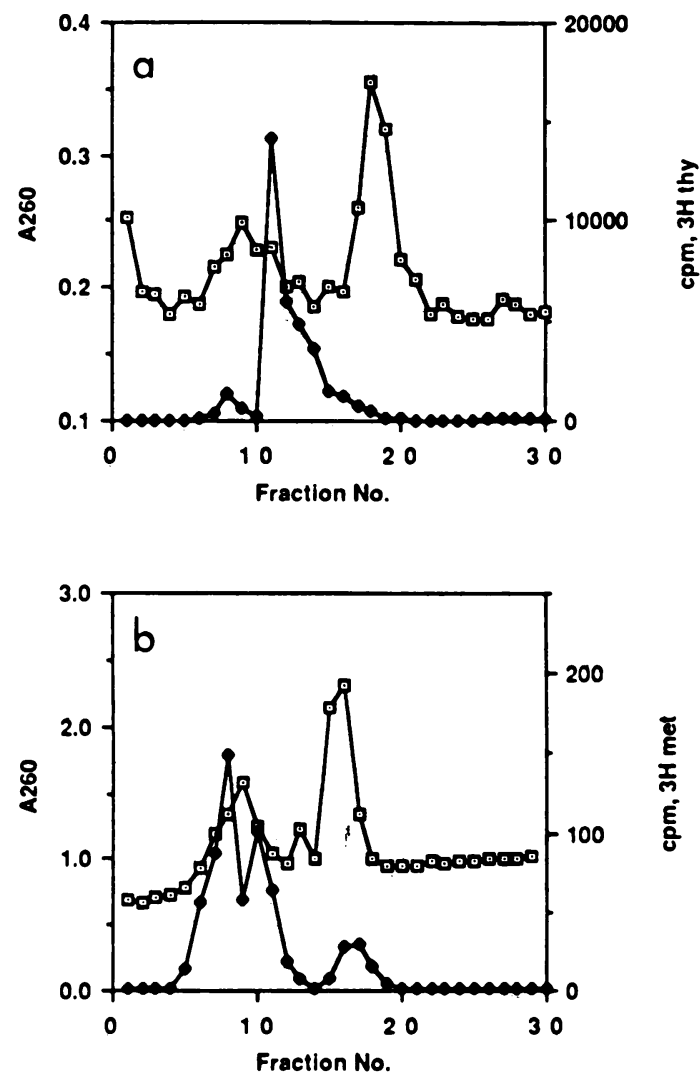

FIG. 1. Alkaline $\mathrm{CsCl}_{2}-\mathrm{Cs}_{2} \mathrm{SO}_{4}$ gradients of $\left[\right.$ methyl- $\left.{ }^{3} \mathrm{H}\right]$ thymidine- (a) and $\mathrm{L}-\left[\right.$ methyl $\left.^{3} \mathrm{H}\right]$ methionine- (b) labeled DNA from cells cultured vegetatively in the presence of BUdR. Density decreased as the fraction number increased. Symbols: $\odot, A_{260} ; \mathbf{\square}$, counts per minute per $100 \mu$ l of sample. 

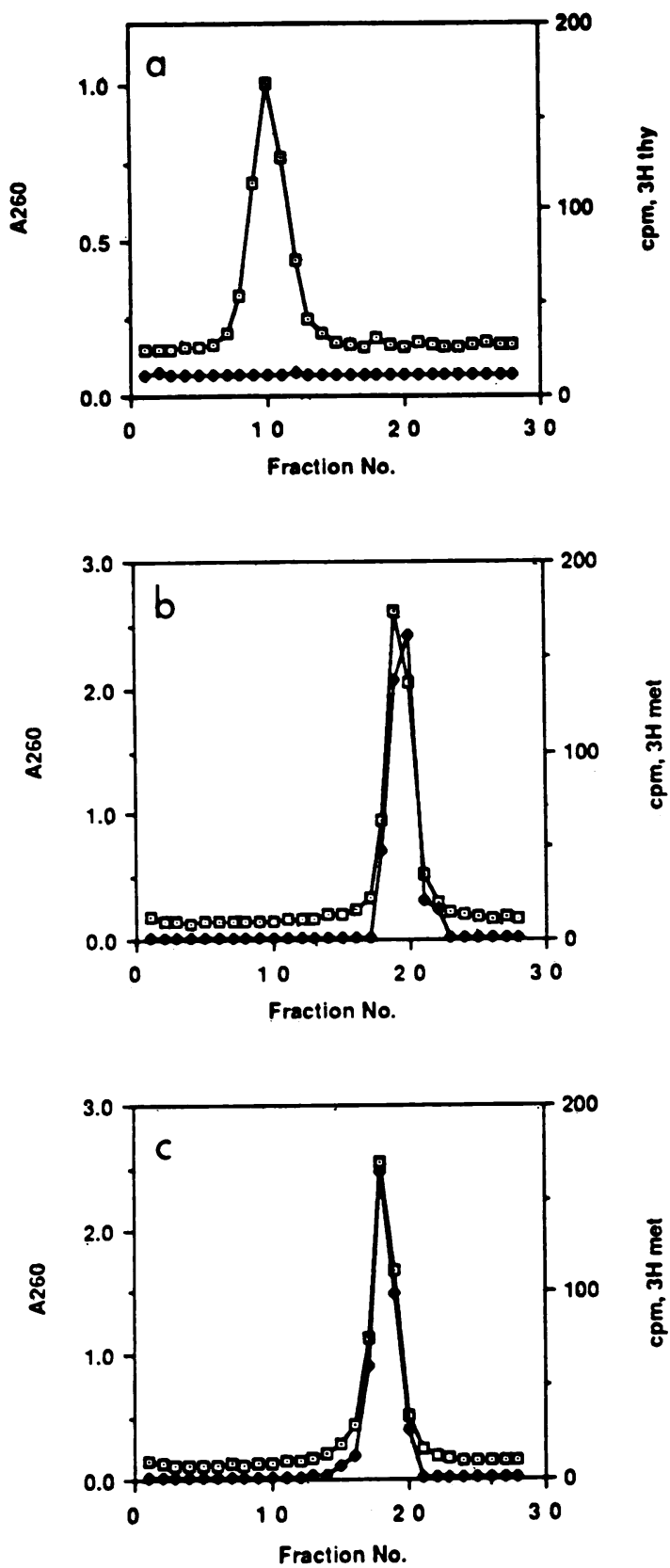

FIG. 2. Alkaline $\mathrm{CsCl}_{2}-\mathrm{Cs}_{2} \mathrm{SO}_{4}$ gradients of $\left[\right.$ methyl- $\left.{ }^{3} \mathrm{H}\right]$ thymidine- (a) and $\mathrm{L}-\left[\right.$ methyl $\left.-{ }^{3} \mathrm{H}\right]$ methionine- $(\mathrm{b}$ and $\mathrm{c}$ ) labeled DNA from cells starved in $10 \mathrm{mM}$ Tris. Cells were cultured in the presence (a and b) or absence (c) of BUdR. Gradients in panels $b$ and $c$ were run in a separate experiment from the gradient in panel $a$, which accounts for the difference in elution of the unreplicated (light) DNA. Symbols: $\oslash, A_{260} ; \square$, counts per minute per $100 \mu$ l of sample.

radioactivity comigrating with unreplicated (light) DNA. About $13 \%$ of incorporated counts were in this peak, suggesting that a significant fraction of methylation in replicating DNA occurs on the parental strand.

Methylation of unreplicated DNA. Autoradiography of cells starved in the presence of $\left[{ }^{3} \mathrm{H}\right]$ thymidine previously indicated that starved cells do not synthesize DNA (7). This was confirmed by density gradient analysis of DNA from
TABLE 1. DNase I digestion of $\mathrm{L}-\left[\right.$ methyl $\left.-{ }^{3} \mathrm{H}\right]$ methionine- and $\left[8-{ }^{3} \mathrm{H}\right]$ adenine-labeled DNA

\begin{tabular}{lcc}
\hline \multirow{1}{*}{ DNA treatment } & \multicolumn{2}{c}{$\begin{array}{c}\text { cpm (\% recovery) of DNAs } \\
\text { labeled with: }\end{array}$} \\
\cline { 2 - 3 } & $\begin{array}{c}\text { L- }\left[\text { methyl }-{ }^{3} \mathrm{H}\right] \\
\text { methionine }\end{array}$ & {$\left[8-{ }^{3} \mathrm{H}\right]$ adenine } \\
\hline $\begin{array}{l}\text { Minus DNase I } \\
\text { Before filtration } \\
\text { After filtration (bound to filter) }\end{array}$ & 100 & 192 \\
& $56(56)$ & $151(79)$ \\
$\begin{array}{l}\text { Plus DNase I } \\
\text { Before filtration } \\
\text { After filtration (bound to filter) }\end{array}$ & 110 & 135 \\
\hline
\end{tabular}

starved cells (Fig. 2a). Log-phase T. thermophila was transferred to $10 \mathrm{mM}$ Tris and starved for 22 to $24 \mathrm{~h}$, BUdR and $\left[{ }^{3} \mathrm{H}\right]$ thymidine were added to the medium, and the cells were maintained for an additional $18 \mathrm{~h}$ before DNA extraction. When the DNA was run on an alkaline $\mathrm{CsCl}_{2}-\mathrm{Cs}_{2} \mathrm{SO}_{4}$ gradient, there was a single peak, as measured by determining the $A_{260}$, and there was no evidence for the incorporation of $\left[{ }^{3} \mathrm{H}\right]$ thymidine.

Although DNA synthesis was below detectable levels in starved cells (Fig. 2a), DNA methylation occurred nonetheless (Fig. $2 b$ and c). The addition of $\left[{ }^{3} \mathrm{H}\right]$ methionine to medium containing starved cells resulted in the incorporation of label into DNA both in the presence (Fig. 2b) and the absence (Fig. 2c) of BUdR. Since we demonstrated that starved cells do not synthesize DNA, incorporation of $\left[{ }^{3} \mathrm{H}\right]$ methionine must have occurred in the absence of DNA replication.

We showed that radioactivity incorporated by labeling with $\left[{ }^{3} \mathrm{H}\right]$ methionine was in DNA and not protein by two criteria. The first was that the counts were sensitive to digestion with DNase I. Table 1 shows the result of digesting $0.5 \mu \mathrm{g}$ of DNA from cells which were labeled in vivo with either $\left[{ }^{3} \mathrm{H}\right]$ methionine or, as a control, $\left[8-{ }^{3} \mathrm{H}\right]$ adenine. Following DNase I treatment, DNA was coprecipitated from $10 \%$ trichloroacetic acid with $50 \mu \mathrm{g}$ of calf thymus DNA. The majority of counts were released by DNase I digestion, with only 6 to $8 \%$ of the radioactivity remaining bound to the filter.

Thin-layer chromatography of bases was done to show that the DNA was labeled in methyladenine residues. Acid hydrolysis of DNA was performed as described by Hattman (8). The hydrolyzed DNA was spotted, along with standards, onto a silica thin-layer chromatographic sheet containing a UV fluorescence indicator (J. T. Baker Chemical Co., Phillipsburg, N.J.). The difference in migration between adenine and methyladenine was maximized by using an ascending, one-dimensional, two-step solvent system (ethyl acetatemethanol; [70:30] with overnight drying, followed by chloroform-methanol [40:60]). The spots were visualized with UV light, cut out, and counted. Results from one experiment are shown in Table 2 . Guanine and cytosine residues ran as a smear near the origin in this system and were not measured. A total of $58 \mathrm{cpm}(94 \%$ of the total counts per minute measured for the bases adenine, methyladenine, and thymine) was detected in the spot corresponding to $\mathrm{N}^{6} \mathrm{MeA}$, compared with $4 \mathrm{cpm}(6 \%)$ for adenine and $0 \mathrm{cpm}$ for thymine. The $21 \mathrm{cpm}$ measured at the origin probably corresponded to partially hydrolyzed DNA. Thus, label incorporated into the DNA of starved cells was the result of adenine methylation. 
TABLE 2. Thin-layer chromatography of hydrolyzed $\mathrm{L}-\left[\right.$ methyl $\left.{ }^{3} \mathrm{H}\right]$ methionine-labeled DNA

\begin{tabular}{lclc}
\hline Base & $\begin{array}{c}\text { Distance (cm) } \\
\text { migrated from } \\
\text { origin }\end{array}$ & $R_{f}{ }^{a}$ & cpm in spot \\
\hline Thymine & 12.5 & 0.39 & 0 \\
N $^{6} \mathrm{MeA}$ & 11.0 & 0.34 & 58 \\
Adenine & 10.0 & 0.31 & 4 \\
Origin & 0 & 0 & 21 \\
\hline
\end{tabular}

${ }^{a}$ The $R_{f}$ was determined as follows: distance migrated by base/distance migrated by solvent.

We showed that the majority of methylation occurs on the daughter strand during DNA replication in T. thermophila. In addition, there was significant incorporation of label on the unreplicated parental strand in DNA from dividing cells and methylation of nonreplicating DNA in starved cells. One explanation for the methylation of nonreplicating DNA could be the turnover of methyl groups, with no change in steady-state levels. Another possible explanation, at least in growing cells, is delayed methylation, as has been described previously for cytosine in mammalian systems $(5,10,12,18)$. It is unlikely, however, that delayed methylation accounts for methylation of DNA in starved cells, which was synthesized 22 to $24 \mathrm{~h}$ before the addition of the radioisotope.

Repair synthesis cannot readily account for methylation of nonreplicating DNA in starved cells. The assay for DNA replication in growing cells by labeling with $\left[{ }^{3} \mathrm{H}\right]$ thymidine is 100 -fold more sensitive than labeling with $\left[{ }^{3} \mathrm{H}\right]$ methionine (Fig. 1), yet no DNA synthesis was detected in starved cells. It is unlikely that DNA synthesis was masked in starved cells by a large pool of unlabeled thymidine, since replicating DNA is readily labeled by thymidine incorporation when starved cells with complementary mating types are mixed to induce conjugation (7). These results indicate that DNA methylation occurs in the absence of DNA synthesis in $T$. thermophila and are consistent with the hypothesis that unmethylated sites are a substrate for a maintenance methylase.

This work was supported by Public Health Service grants GM 32989 and GM39890 from the National Institutes of Health.

\section{LITERATURE CITED}

1. Blackburn, E. H., W.-C. Pan, and C. C. Johnson. 1983. Methylation of ribosomal RNA genes in the macronucleus of Tetrahymena thermophila. Nucleic Acids Res. 11:5131-5145.
2. Cummings, D. J., A. Tait, and J. M. Goddard. 1974. Methylated bases in DNA from Paramecium aurelia. Biochim. Biophys. Acta 374:1-11.

3. Gorovsky, M. A., S. Hattman, and G. L. Pleger. 1973. $\left[{ }^{6} \mathrm{~N}\right]$ methyl adenine in the nuclear DNA of a eucaryote, Tetrahymena pyriformis. J. Cell. Biol. 56:697-701.

4. Gorovsky, M. A., M.-C. Yao, J. B. Keevert, and G. L. Pleger. 1975. Isolation of micro- and macronuclei in Tetrahymena pyriformis. Methods Cell Biol. 9:311-327.

5. Gruenbaum, Y., M. Azyf, H. Cedar, and A. Razin. 1983. Methylation of replicating and post-replicated mouse L-cell DNA. Proc. Natl. Acad. Sci. USA 80:4919-4921.

6. Harrison, G. S., R. C. Findly, and K. M. Karrer. 1986. Sitespecific methylation of adenine in the nuclear genome of a eucaryote, Tetrahymena thermophila. Mol. Cell. Biol. 6:2364 2370.

7. Harrison, G. S., and K. M. Karrer. 1985. DNA synthesis, methylation and degradation during conjugation in Tetrahymena thermophila. Nucleic Acids Res. 13:73-87.

8. Hattman, S. 1970. DNA methylation of T-even bacteriophages and of their nonglycosylated mutants: its role in P1-directed restriction. Virology 42:359-367.

9. Hattman, S., C. Kenny, L. Berger, and K. Pratt. 1978. Comparative study of DNA methylation in three unicellular eucaryotes. J. Bacteriol. 135:1156-1157.

10. Hilliard, J. K., and T. W. Sneider. 1975. Repair methylation of parental DNA in synchronized cultures of Novikoff hepatoma cells. Nucleic Acids Res. 2:809-819.

11. Kidder, G. W., and V. C. Dewey. 1945. Studies on the biochemistry of Tetrahymena. Arch. Biochem. 8:293-320.

12. Kowalski, J., and W. P. Cheevers. 1976. Synthesis of high molecular weight DNA strands during S phase. J. Mol. Biol. 104:603-615.

13. Nanney, D. L., and R. M. Preparata. 1979. Genetic evidence concerning the structure of the Tetrahymena thermophila macronucleus. J. Protozool. 26:2-9.

14. Pratt, K., and S. Hattman. 1981. Deoxyribonucleic acid methylation and chromatin organization in Tetrahymena thermophila. Mol. Cell. Biol. 1:600-608.

15. Rae, P. M. M., and B. B. Spear. 1978. Macronuclear DNA of the hypotrichous ciliate Oxytricha fallax. Proc. Natl. Acad. Sci. USA 75:4992-4996.

16. Van Etten, J. L., A. M. Schuster, L. Girton, D. E. Burbank, D. Swinton, and S. Hattman. 1985. DNA methylation of viruses infecting a Chlorella-like green alga. Nucleic Acids Res. 13: 3471-3478.

17. White, T. C., N. C. McLaren, and S. A. Allen. Methylation site within a facultatively persistent sequence in the macronucleus of Tetrahymena thermophila. Mol. Cell. Biol. 6:4742-4744.

18. Woodcock, D. M., D. L. Simmons, P. J. Crowther, I. A. Cooper, K. J. Trainor, and A. A. Morley. Delayed DNA methylation is an integral feature of DNA replication in mammalian cells. Exp. Cell Res. 166:103-112. 